\title{
Changes of Compulsory Education Policy in China
}

\author{
Xianlong Sun
}

\author{
Dock Mennonite Academy \\ wsun22@dock.academy
}

\begin{abstract}
Since the 72nd anniversary of the founding of The People's Republic of China, the leadership of the state over education has been the key to the development of China's educational cause. In a short period time China continues to develop socialism with Chinese characteristics education policies to promote China by education power gradually education power, thus the purpose of this paper is to after the founding of new China's political and economic change under the macroscopic background of the summary of the development of China's education reform and (not discuss China's stagnant decade). The emphasis is laid on the institutional change and innovation in the process of education, according to characteristics of the situation analysis of the evolution, as to break through the obstacles of existing system structure. With the development of The Times, even though the education policy with Chinese characteristics has made some achievements, it still needs to continue to improve and supplement from the aspects of theory and practice in the future, and continue to improve the education policy based on national conditions. Through literature survey, it is found that Chinese education is gradually becoming mature with the changes of times and policies.
\end{abstract}

Keywords: compulsory education policy, educational changes, China's education reform.

\section{INTRODUCTION}

The formulation and implementation of educational policy have tremendous and far-reaching influence and significance on the educational development of a country or region. The development and change of China's unique educational system is closely related to the reform of the country's political system. History of Education in China can be divided into three stages: the basic stage of Education in China, education seeking development direction, and education reform. For many years, the education reform and education reform has experienced different stages of development, including basic education, the education, and education reform, to explore based on market mechanism to promote the development of education system reform, adjust the education policy, from efficiency to justice, promote the comprehensive reform in the field of education, accelerate the modernization of education management system and improve the capability of governance. China's compulsory education is faced with many problems in the development process, and the compulsory education policy cannot effectively solve all the problems in each historical stage[6]. Only the constantly changing compulsory education policy can make compulsory education develop healthily and full of vitality. The purpose of this paper is to summarize the process of education policy changes since the founding of China, including the mechanism of China's education system and the changes and impacts of current policies.

\section{AFTER THE FOUNDING OF THE PEOPLE'S REPUBLIC OF CHINA UNTIL 2008}

\subsection{9-1958 foundation period}

Between 1949 and 1958, China borrowed and learned from the former Soviet Union. The founding of new China, there was only one small number of people went to school or even had essential reading and writing skills, so the Party and state paid particular attention to primary education. As early as 1949, The chairman MAO reiterated that China should follow the example of the Soviet Union. Therefore, after the founding of the People's Republic of China, the vice minister of education said that learning from the Soviet Union was the main direction of education development, thus creating a new education system. The Constitution of the People's Republic of China adopted at the First Session of the National People's Congress in 1954 stipulates: "Citizens of the People's Republic of China 
have the right to receive an education. We will establish and gradually expand schools and other cultural and educational institutions to ensure that citizens enjoy this right." This is the fundamental provision of the state on the form and purpose of education in New China [3]. As a result, early education in China is called "semicompulsory" by most people. However, the Chinese government subconsciously protects the rights of ordinary people, while encouraging local residents to open new educational institutions, whether private, private or collective. While the government did turn its attention to ensuring the rapid recovery, stabilization and reorientation of primary schools, much of its shift was directed at reforming higher education policy.

The Chinese government has adopted a Soviet-style education model, emphasizing engineering projects and productive labor. During this period, school attendance grew rapidly, and The Soviet educational policy did not solve the general problem of low education. This is because the government has not focused on education welfare in specific education policies; they do not understand the fundamental status of compulsory education in education welfare and do not understand the importance of meeting the needs of people's survival and development. From the perspective of the several features of compulsory education simultaneously, this stage of education development is not mature. The policy is not perfect; it has formed a centralized and rigid system. Students choose courses, teachers, or mechanism design study plan or identify individual freedom of the course content rarely, departments and professional, strict organization mean the interdisciplinary collaboration even contact space is small. Therefore, the educational policy of this stage became the period that laid the foundation of Chinese education[8]. With China and the USSR, after the collapse of the Soviet Union in 1960, "borrowing from the Soviet Union" was no longer seen as a model, and the government began to redesign the curriculum to show a balance between eastern beauty and Western education. The education system has been transformed into Dual School System, with less strict standards of content and quality accepted by the masses.

\subsection{Rest period from 1976 to 2008}

From 1976 to 2008, education's recovery period benefited from Deng Xiaoping's education policy of "respecting knowledge and talents," which aroused the public's respect and attention to education. From 1976 to 1985 , the whole education system was restored and adjusted, especially after the reform and opening up; the focus of the basic education reform was to improve the quality of education. Thanks mainly to education policies since Deng Xiaoping came to power, many reforms have been carried out in China, while the transition to a The market economy under the socialist system needs trained labor force to support the economic development at the same time, it also needs highly educated labor force. Reform of the education system has become a national priority. The quality of education is far more important than quantity, curriculum and education teaching methods are once again borrowed from abroad for advanced scientific training. Rural primary and secondary schools were widely dispersed and merged, teaching talents and funds quickly returned to cities, and urban primary education developed rapidly. At the same time, the enrollment rate of school-age children and primary school graduates in rural areas has continued to decline. At that time, the central government took note of the phenomenon and issued a series of documents calling for strengthening primary education in rural areas.

In the situation of shortage of talents and educational resources, Chairman Deng Xiaoping stressed that "there are two ways to develop education: one is to popularize education and the other is to improve education. It is also important to build key primary schools, key middle schools and key universities. Therefore, the construction of key schools has historical significance to develop important people, quickly producing talents and quickly producing talents" and meeting the country's demand for educated talents and talents [2]. After 1976, education gradually recovered and rebuilt, and educational institutions also recovered and rebuilt during this period, but there were still many problems: teachers and students thought that there were many problems in the education system; for example, the government's education packages were too much, too much control, education connection, backward educational methods, unreasonable educational institutions and so on. It was not until the "Decision on Education System Reform" issued by the Central Committee in 1985 that education and schools were unbound by streamlining administration and delegating power, which re-stimulated the educational vitality of teachers and students [9].

Until the 1980s, China's basic education was still weak, and several poor areas were not able to provide universal primary education. Many school-age children, especially girls, did not have a chance to accept rules fixed number of years of primary school education, and many teachers of primary and middle school students lack proper teaching training. Teacher's professional skill under the national standard, lack of teaching equipment is also a severe problem, Until the promulgation of "Compulsory Education Law" [3]. The Compulsory Education Law, adopted in 1986 and put into effect, strictly regulates the number of years for children to enter school according to law, the guardians for children to receive compulsory education, the primary schooling system, and the management system, all of which have become milestones in the development of education. With the rapid development 
of China's economy, economic and social development has made significant progress and caused the development imbalance.

Since 2003, the Ministry of Education proposed to study and implement the spirit of the 16th National Congress of the People's Republic of China, take development as the theme, adhere to the comprehensive and scientific concept of development, vigorously promote education informatization, promote the development of education. At the same time, the focus of education reform has shifted from universal education to educational equity, such as stopping arbitrary tuition fees. The compulsory education institutions of the education fee publicity system, "one fee system," and "three policies and three restrictions policy" have passed the high school selection fee standard, strengthening the control of arbitrary fees. Actively promote compulsory education balanced development, from the Ministry of Education proposed "actively promote compulsory education balanced development." Since the "balanced development" has become "the strategic task of compulsory education" to implement the "nine-year compulsory education balanced development" and "the integration of urban and rural compulsory education as a whole," gradually set up the mechanism of rural compulsory education financial security, Improve the central and local public financial institutions that share the balanced development of compulsory education by project and proportion [2]. In line with this development direction, education policy seeks peace among all parties, strives to maintain order and stimulate the enthusiasm and vitality of all parties.

\section{FROM LATE 2014 TO THE PRESENT}

After years of development, China's education has been constantly improved. In addition, the Compulsory Education Law also stipulates that children and adolescents who have studied for a certain number of years according to law should be guardians of compulsory education, basic issues such as the basic length of schooling and management system of compulsory education, and channels and basic standards for the financing of compulsory education. After decades of development, China's compulsory education has basically achieved "universal." It is now in a new stage of development: from pursuing a quantity to the pursuit of quality, improving the quality of education, a balanced allocation of educational resources, the social demand for education equity is becoming stronger and stronger. For China's education, the 40 years of reform and opening-up is a process of restoring and rebuilding social order, removing institutional obstacles, and stimulating social vitality. It transforms from a planned economy to a market economy through unified, centralized management and multi-party participation in the education system.

In 2014, the Ministry of Education, the National Development and Reform Commission, and the Ministry of Finance jointly launched the plan for improving the Basic Conditions of Compulsory Education Schools in Poor Areas. According to the plan, 50 billion yuan will be invested in five years to improve underdeveloped schools' teaching conditions and infrastructure comprehensively. The plan will finance the construction of rural school buildings and playgrounds and the purchase of desks and chairs, science laboratory equipment, equipment to provide drinking water, and the construction of canteens and dormitories in boarding schools. In addition to funds, the implementation of financial management support for rural primary and secondary schools to ensure effective use of funds. Some pilot areas have already established budget and payment management systems. In this system, the educational affairs department is responsible for the school's financial management, management, and supervision [7]. Teachers' requirements are also stipulated. Under the new system, teacher qualification tests are held nationwide, and schools and other educational institutions should gradually adopt system contracts for hiring teachers.

China's economic development has brought large numbers of immigrants, which has created new problems for neighbourhood attendance policies. When families move, migrant children must change schools. Neighbourhood attendance policies will make it difficult for migrant children to attend schools in the new district. To address this problem, local governments have adopted a series of measures following the Compulsory Education Law to ensure that every child has access to compulsory education. For example, after the notice on Improving the education of migrant children in 2003, local governments prohibited public schools from charging migrant students extra fees. Recently, more policies have been introduced to implement the visiting policy further. These policies prohibit entrance examinations for compulsory education and fees for school choice. Lawmakers also established open enrolment procedures to ensure a fair enrolment system. At the same time, more specific strategies have been formulated to ensure the highquality and balanced development of compulsory education throughout the country [7]. In addition, the adult illiteracy rate dropped to around 5\% in 2014 (China National Bureau of Statistics, 2015). Admittedly, the existing education system has not kept up with the needs of economic development and the public's demand for education. At present, the Chinese government prioritizes the political and financial development of education, showing its determination to build a better education system. 


\section{CONCLUSION}

China's educational reform is a process of perfecting the mechanism of educational institutions and establishing educational institutions under the socialist system. This is a process in which educational policies and regulations promote reform, educational organizations are regulated by law, and educational institutions are built and perfected. China has most extensive education system in the world, with nearly 260 million students and teachers in about 514,000 schools (National Education Bureau China Statistics, 2014), excluding graduate education institutions, China's education system is not only vast and diverse. The educational reform process explores the game and rational allocation of power and interest, reconstructs the educational order, and breaks the shackles. The process of education reform is a process from regulation to empowerment, which is promoted by legal empowerment, joint consultation, and joint governance. The main task of the education system reform is to establish a new era and improve the "government macro management mode, run schools according to law and run schools according to law. The society should participate in an orderly way and all parties should make joint efforts to "run education well". is "full of vitality, more efficient, more open, more conducive to scientific development"

In the future, the task of education development is to promote the balanced development of education further, solve the problem of unbalanced and inadequate development, and meet the people's growing demand for education equity and higher quality (CAI, 2017)[1]. Compulsory education policy not only reflects the change in a specific historical stage, China reflects the main problems existing in the process of the compulsory education development, can also play a role of anti-India effectively, promote the change of the different stages of history education policy, but these changes are also showing China's compulsory education policy gradual democratization process, significantly improve the effectiveness of citizen participation, It is this policy that has benefited compulsory education. On December 27, 2005, the Chinese government announced that China would invest 218 billion yuan (27.25 billion US dollars) in the next five years to help improve rural education. In addition, China will exempt students of nine-year compulsory education from all tuition and miscellaneous fees within two years and provide textbooks and subsidies to students from lowincome families (TAO et al., ND)[4].

This paper compares and summarizes China's education policies in different periods of time through a literature survey, and finds that China's education is changing over time and national policies, from immature to mature.

\section{REFERENCES}

[1] Cai, J. (2017). Education reform enters the stage of "comprehensive construction interior decoration". China Education Daily, 2017-10-20(1). https://scholar.google.com/scholar?q=Cai\%2C\%20 J.\%20\%282017\%29.\%20Education\%20reform\%2 0enters $\% 20$ the $\% 20$ stage $\% 20$ of $\% 20 \%$ E2\%80\%9Cc omprehensive $\% 20$ construction $\% 20$ interior $\% 20 \mathrm{dec}$ oration\%E2\%80\%9D.\%20China\%20Education $\% 2$ 0Daily\%2C\%202017-10-20\%281\%29.

[2] Guorui Fan (2020) Changes in Educational Institutions in China: 1978-2020 https://link.springer.com/chapter/10.1007/978-98113-8347-2_6

[3] Ran Min (2007) Historical changes and Functional analysis of China's compulsory education policy https://www.doc88.com/p-30839870959116.html

[4] LIQING TAO, MARGARET BERCI and WAYNE HE Historical Background: Expansion of Public Education https://archive.nytimes.com/www.nytimes.com/ref/ college/coll-china-education-001.html

[5] Yifan ma(2010) Curriculum change under the influence of new China's higher education policyhttps://www.doc88.com/p3085592487874.html

[6] SiWeiWei(2007)Research on the policy changes of Special education in China https://www.doc88.com/p-5196375941237.html

[7] Education in China A SNAPSHOT (2016) https://www.oecd.org/china/Education-in-China-asnapshot.pdf

[8] Stian Håklev (2010) Russia's influence on Chinese higher ed - 1949-1958 http://reganmian.net/blog/2010/10/02/russiasinfluence-on-chinese-higher-ed-1949-1958/

[9] ChanDaSheng (2019) The 70-year Change and Future development of Chinese education https://www.doc88.com/p-6671621361129.html 